DOI https://doi.org/10.30525/978-9934-588-79-2-2.37

\title{
ANALYSIS OF THE ODESSA CITY'S TRANSPORT INFRASTRUCTURE AND PROSPECTIVE WAYS OF MAIN PROBLEMS SOLVING
}

\author{
Lapkin Alexander \\ Postgraduate Student, \\ Head of Laboratory Department of Management and Marketing \\ Maritime Business Institute of the Odessa National Maritime University \\ Odesa, Ukraine
}

The development of transport infrastructure is one of the most pressing issues of urban life. It is known that the transport network of any city is the basis around which urban planning takes place. In recent decades, the transport infrastructure of Odessa has developed under the influence of many factors. First of all, the following should be noted: the relative stability of the city's population (up to 2001 - 1001 thousand people, 2005 - 989 thousand people, 2011 - 991 thousand people, 2017 - 993 thousand people) [1] ; above the active development of housing construction in the city itself, and in its immediate suburbs; increase in the number of cars per capita from 75 units. per thousand inhabitants in 1991 to 202 units. in 2013, as well as at least $10 \%$ over the past two years due to changes in legislation $[2 ; 3]$.

Thus, with a seemingly stable number of residents of Odessa, there is an active increase in the area developed for housing, growth as average distances from places of mass new construction to the central part of the city, as well as a dramatic increase in built-up areas in already developed areas of the central part. This, along with changes in the structure of employment and the level of prosperity of the population living in new buildings, leads to an additional increase in the mobility of the population as a whole, and especially sharply - in certain areas.

It should be noted that the pace of development of the road network in the 2000s was clearly regressive. Road programs of this period mainly provided for the maintenance of the condition of the roadway and sidewalks within the existing norms of those realities; the directions of traffic flows through the main streets of the city were changed and transformed by changing the traffic rules (with one-way traffic, without turns, etc.). The capacity of the streets has not changed. 
Maritime passenger transport of short radius of transportation, which in previous times was given enough attention, both by modern for the relevant period of technical characteristics of vehicles, and by the organization of urban transport $[4,5]$, was removed from city life and transferred to the category of tourist entertainment.

Analyzing the transport infrastructure of Odessa, it should be noted the main changes that have occurred in the work of public transport in the city in recent years. First, for many decades, the program of urban transport renovation was carried out by poorly justified actions and bright single copies, and not by a real change of rolling stock. Secondly, all plans to expand and optimize existing street transport (high-speed tram) have not been implemented. Third, no work is being done to create alternative offstreet modes of transport (monorail, «sea trams»). Fourth, due to the increase in the number of cars and the need to park them, all the work on the expansion and optimization of the road area at the expense of sidewalks is leveled by the accessible carriageway. In addition, an important addition to the public transport system was the network of minibuses, which was chaotically formed in market conditions.

These negative changes are due to the lack of an effective program of urban planning and public transport management. Suffice it to say that the construction of roads, the functioning of the land transport system and urban planning are the responsibility of various departments of the City Administration (Department of Roads, Department of Capital Construction, Department of State architectural and construction control, management of engineering protection of the city and coastal development).

The analysis of statistical information, collection of materials in various periodical sources, as well as the study of the General Plan of Odessa and other normative documents, allowed to identify the seven most significant categories of transport problems in Odessa that currently exist.

1. Insufficient number of road facilities to connect the central part of the city with the neighborhoods.

The problem of transport communication between the central part of Odessa and the «sleeping areas» is one of the most important for the development of the city. The composition of Odessa's transport infrastructure was influenced by political, economic and cultural processes, and the pace of the city's development was constantly changing.

2. Lack of development of «highways» of the city.

Rapid motorization, the development of suburbs, the growth of country and cottage construction, complemented by increased passenger traffic, stimulated by market and social transformations of the post-Soviet period, 
led to a significant increase in pendulum migration and an overall increase between Odessa and Odessa region.

3. Insufficient development of connecting elements of infrastructure between the centers of origin of transport flows.

This problem is caused by the presence in the center of the railway station and port and the corresponding railway / road routes leading from the outside. This is due to the fact that these objects were laid in the early XX century. Over time, the growing city filled the vacant spaces around the railways and the port area.

4. Limited opportunities for traffic and parking in the central part of the city.

As noted above, in the central part of the city there is a significant number of places to attract the population (offices of institutions and various firms, educational institutions, many shops, restaurants, cafes and other service facilities). Opportunities to expand the road network in the central part and in densely populated areas are almost completely absent due to the fact that most of the city is the only architectural monument that is part of the materials submitted to the UNESCO World Cultural and Natural Heritage on the one hand, and beyond private property, on the other.

5. Lack of development of the street transport system.

In conditions of heavy traffic on the road network, the only alternative to a car may be the development of public transport and, above all, offstreet (such modes of transport traditionally include subway, light rail, monorail, high-speed tram, sea tram). Given the geographical location of Odessa Bay, the logical proposal is to restore the service of «sea tram» service. In Soviet times, the coastal boat service covered the entire Odessa coast from Luzanovka to the Black Sea. Due to the opportunity to visit the sea, see the coast, as well as due to the low cost (less than 1 ruble), «sea trams» were very popular. However, later, due to the failure of berth complexes outside the port of Odessa, sea voyages became possible only from the port itself. Therefore, while maintaining the pleasure component, the role of boats as vehicles for passenger transport was lost. However, now the start of such a project with the support of the state is quite possible. Work in this direction was carried out in 2015, it was planned to install temporary floating berths and use 5 boats at the disposal of the seaport.

6 . Lack of a city network of bicycle paths.

Currently, the possibility of using a bicycle or its analogues as vehicles is clearly underestimated. There are almost no dedicated lanes for cyclists in the city center. Although in large and densely built-up cities in Europe, where, like us, there are changes in weather conditions from snowy winters 
to hot summers, the bicycle and its analogues have long been an important vehicle. In particular, in some European cities, such as Copenhagen, bicycle lanes are being built even if the size of the pedestrian streets is reduced.

7. Lack of modern public transport connecting urban areas with the airport and the Industrial Market.

The solution to the problem, as well as a way to increase the comfort of passengers, may be the creation of a new line of off-street transport - railway express by analogy with projects in other cities, but not only to connect with the airport but also the Industrial Market.

Conclusions. Summing up the results of consideration of the existing transport problems of Odessa, it should be noted that they can be systematized into the following seven groups: insufficient number of road facilities to connect the central part of the city with the neighborhoods; lack of development of highways; insufficient development of connecting elements of the infrastructure between the centers of origin of transport flows; limited opportunities for traffic and parking in the central part of the city; lack of development of the street transport system and the city network of bicycle paths; lack of modern public transport connecting urban areas with the airport and the Industrial Market. The described problems are the basis for initiating projects aimed at solving them.

Given the geographical location of the city, the experience of recent decades of $\mathrm{XX}$ century and returning attention to the revival of coastal maritime transport in the recent period, a logical proposal among the projects for the development of the non-street transport system is the restoration of maritime coastal services. The concomitant goal of preserving and disseminating the pleasure component is to use coastal passenger ships as means of transport for passengers. The further state of the economy of the city and the region as a whole depends on the quality and development of transport infrastructure, convenience and comfort of urban transport connections for residents and guests of our city.

\section{References:}

1. City population, UN. URL: http://data.un.org/ (date of reference: 24.09.2019)

2. Rost Kolichestva Avtomobiley. AutoConsulting. Infirmatsionno Analiticheskaya Gruppa. URL: http://www.autoconsulting.com.ua (date of reference: 24.09.2019) [in Russian]

3. Lapkin O.O. (2019) Logistichniy aspect proektu transnatsional'noi dostavki avtomobiliv (The logistic aspect of the transnational car delivery project / Proektiy ta logistichniy menedzhment: novi znannya na bazi dvoh 
metodologiy (Project and logistics management: new knowledge based on two methodologies) // [I.O. Lapkina, V.O. Andrievskaja, V.U. Smrkovskaja and oth.] Vol. 2. Monograph. Odesa: KUPRIENKO SV. 170178 [in Ukrainian]. DOI. 10.21893/2616-8936.2019-02.

4. Petuhov V.S. (1970) Organizaciya morskih passazhirskih perevozok $v$ mestnom soobschenii (Organization of maritime passenger transportation in local communication). M: Transport. 152 [in Russian],

5. Shibaev A.G. (2013) Passazhirskije perevozki (Passenger transportation) / A.G. Shibaev, G.N. SiVvanskaja, I.M. Petrov. Odessa: Feniks. 336 [in Russian],

DOI https://doi.org/10.30525/978-9934-588-79-2-2.38

\title{
SCIENTIFIC METHODOLOGICAL APPROACH TO DETERMINING THE TYPE AND PARAMETERS OF CROSS-COUNTRY TRANSPORTATION
}

\author{
Mishchenko Ya. S. \\ $P h D$ in Technical Science, \\ Senior Lecturer at the Department of Armored Vehicles \\ Hetman Petro Sahaidachny National Army Academy \\ Kuprinenko O. M. \\ $P h D$ in Technical Sciences, Senior Scientist Researcher, \\ Head of the Department of Armored Vehicles \\ Hetman Petro Sahaidachny National Army Academy \\ Lviv, Ukraine
}

Dispute over which is better wheeled running or tracked running gear for cross-country transportation (CCT) continues today.

Means of transport with wheeled running gear in comparison with the tracked running gear have got better mileage rating and reliability (longer reserve maintenance period), much lower cost of production and operation, better adapted to traffic on surfaced road with higher speeds without destroying roads.

Considering the complexity of the mechanics of the interaction of the vehicles with the terrain [1], there is ambiguity in the choice of type and parameters of the CCT engine for their rational use in a particular geographical area. 